DEMOGRAPHIC RESEARCH

VOLUME 35, ARTICLE 10, PAGES 253-282

PUBLISHED 10 AUGUST 2016

http://www.demographic-research.org/Volumes/Vol35/10/

DOI: 10.4054/DemRes.2016.35.10

Research Article

Uncertain lives: Insights into the role of job precariousness in union formation in Italy

\title{
Daniele Vignoli
}

\section{Valentina Tocchioni}

\section{Silvana Salvini}

(C2016 Daniele Vignoli, Valentina Tocchioni \& Silvana Salvini.

This open-access work is published under the terms of the Creative Commons Attribution NonCommercial License 2.0 Germany, which permits use, reproduction \& distribution in any medium for non-commercial purposes, provided the original author(s) and source are given credit. See http:// creativecommons.org/licenses/by-nc/2.0/de/ 


\section{Contents}

1 Introduction $\quad 254$

$2 \quad$ Employment uncertainty and union formation 255

$2.1 \quad$ Main perspectives... 255

$2.2 \quad \ldots$ and their operationalization $\quad 257$

$3 \quad$ The Italian setting 258

3.1 Changes in the labor market and union formation in Italy 258

$\begin{array}{ll}3.2 & \text { Contrasting research hypotheses } \\ \end{array}$

$4 \quad$ Data and methods $\quad 260$

4.1 Qualitative analysis 260

4.2 Quantitative analysis 262

$5 \quad$ Results 263

5.1 Qualitative findings 263

$\begin{array}{ll}5.2 & 266\end{array}$

$6 \quad$ Concluding discussion $\quad 270$

$7 \quad$ Acknowledgments 273

8 Discussion 221

$\begin{array}{ll}\text { References } & 274\end{array}$

$\begin{array}{ll}\text { Appendix } & 280\end{array}$ 


\title{
Uncertain lives: Insights into the role of job precariousness in union formation in Italy
}

\author{
Daniele Vignoli ${ }^{1}$ \\ Valentina Tocchioni ${ }^{2}$ \\ Silvana Salvini ${ }^{3}$
}

\begin{abstract}

\section{BACKGROUND}

Growing economic uncertainty has become an intrinsic characteristic of contemporary globalized societies in which an increasing number of people are moving in and out of jobs that may give little meaning to their lives. Among other things, economic uncertainty may affect union formation practices.
\end{abstract}

\section{OBJECTIVE}

In this study we address the relationship between employment uncertainty and union formation in Italy. The country typifies a unique case-study in light of its familistic organization, but remains largely under-studied in this respect.

\section{METHODS}

We adopt a mixed-method approach. The qualitative analysis - conducted with focus group techniques - provided an in-depth understanding into the mechanisms of how job precariousness may affect individual perceptions and beliefs on union formation in Italy. The quantitative analysis - conducted through event-history techniques - verified how strong these mechanisms are at the population level.

\section{RESULTS}

The qualitative exploration allows us to advance the hypothesis - new for the Italian setting - that labor market uncertainty favors cohabitation while employment stability facilitates marriage. The subsequent quantitative analysis provided strong support for this hypothesis for the female population. For men, the largest contrast was found between any work and no work.

${ }^{1}$ Università degli Studi di Firenze, Italy. E-Mail: vignoli@disia.unifi.it.

${ }^{2}$ Università degli Studi di Firenze, Italy.

${ }^{3}$ Università degli Studi di Firenze, Italy. 


\section{CONTRIBUTION}

Our findings support the idea that in Italy cohabitation - in contrast to marriage - is more compatible with employment uncertainties of today's labor market. These reflections are valid for women and employed men: When faced with uncertain prospects, they seem to prefer cohabitation to marriage in the light of its more uncertain nature. Alternatively, they might decide to postpone marriage until their outlook on life is more optimistic.

\section{Introduction}

Although presented as the remedy for economic problems and unemployment since the 1990 s, the diffusion of new forms of flexible and temporary work contracts has transformed labor market entry and exit conditions, leading to an increasing precariousness of employment careers. Growing uncertainty has become an intrinsic characteristic of contemporary 'globalized' societies, caused by deregulation, internationalization, and delocalization (e.g., Blossfeld and Hofmeister 2006; Blossfeld, Mills, and Bernardi 2006). From the beginning of the 1990s up to 2012, the share of temporary employment rose from $10 \%$ to $16 \%$ in the Euro area (Caroli and Godard 2013; OECD 2002). Today a growing number of people - the emerging class of 'precariat' (Standing 2011) - are faced with uncertainty, moving in and out of jobs that may give little meaning to their lives.

Uncertainty has spread into the partnership and parenthood domains of young adults' lives as well (e.g., Blossfeld et al. 2005; Kreyenfeld, Andersson, and Pailhe 2012; Mills and Blossfeld 2013). Among other things, economic uncertainty may affect union formation practices. American research generally supports the view that poor economic prospects for men and women are associated with a delay in marriage, and may favor cohabitation. The European literature is more limited in this respect, although some examples can be found especially in the context of the comparative project proposed by Blossfeld and colleagues; Blossfeld et al. 2005). This paper contributes to the European literature on the topic by providing insights into the influence of job precariousness on the decision of women and men to enter either cohabitation or marriage in Italy. The Italian setting typifies a unique case study. In the country, unmarried cohabitation is far less common than elsewhere in Europe and does not yet represent an integral part of family life (Rosina and Fraboni 2004). The 
prolonged absence of the legal recognition of civil unions ${ }^{4}$ combined with familial and social pressure to marry further contribute to leaving little room for cohabitation (Vignoli and Salvini 2014). Nonetheless, contemporary Italy faces an increasing breakdown of marriage, the diversity of union patterns is growing, and a slow but continuous process of secularization is at play (Pirani and Vignoli 2016; Sansonetti 2009). Thus, the focus on the Italian setting is important for eliciting the role of economic uncertainty in driving union formation practices when a society is undergoing secularization and revolutionary family changes.

This paper adopts a mixed-method approach. The qualitative analysis - conducted with focus group techniques - provides an in-depth understanding into the mechanisms of how job precariousness may affect individual perceptions and beliefs on union formation. Then, using quantitative analysis - conducted through event-history techniques - we test how strong these mechanisms are in the general population. We continue by presenting our theoretical considerations, describing the Italian context, and deriving our research hypotheses. This is followed by a presentation of the analytical strategy, and a description of results. A concluding discussion closes the paper.

\section{Employment uncertainty and union formation}

\subsection{Main perspectives...}

The link between employment uncertainty and family formation practices is multifaceted. At first glance, and in line with the globalization and labor market deregulation perspective (Blossfeld et al. 2005; Blossfeld and Hofmeister 2006; Blossfeld, Mills, and Bernardi 2006; Mills and Blossfeld 2013), it is relatively straightforward to suppose that marriage, a resource-intensive and long-term commitment, will be postponed when people face employment uncertainty. According to the uncertainty hypothesis developed by Oppenheimer (1988), especially men's unstable careers, as indicated by low-status jobs, non-employment, and irregular and temporary employment, embody uncertainty. This employment uncertainty impedes assortative mating, and may therefore delay marriage. Furthermore, the spread of job precariousness jeopardizes financial resources, and may thus act as a barrier to marriage or a wedding ceremony (Livi Bacci 2008). Nevertheless, according to the narrative inspired by the socio-psychological uncertainty reduction theory developed by

\footnotetext{
${ }^{4}$ Italy has legally recognized civil unions since 5 June 2016.
} 
Friedman and colleagues (1994), the decision to marry may also serve as a strategy to reduce biographical uncertainty. This theory contends that uncertainty reduction is an immanent value, and that rational actors will always seek to reduce uncertainty. Accordingly, women may respond to unfavorable employment prospects by choosing the 'alternative career' of wives (and mothers) to structure an otherwise uncertain life course.

In recent years, union formation has been increasingly attained not only through marriage, but also through cohabitation. Hence, reflections about the link between economic uncertainty and union formation need to be extended by adding the role of cohabitation. In this respect, the globalization and labor market deregulation perspective may affect cohabitation differently than marriage. In deprived groups or in large-scale economic crises, a pattern of disadvantage (hereafter POD; Perelli-Harris et al. 2010; Perelli-Harris and Gerber 2011) or a "general milieu of social disorganization" (Billy and Moore 1992) may emerge. When social disorganization or 'blocked opportunities' prevail, societal norms on the 'right' order of the life course may lose ground (Bauman 2005). One possible strategy to reduce life course uncertainty is to enter a union, but in this context cohabitation may be preferred over marriage in light of its more uncertain nature (Mills and Blossfeld 2013). Even men's employment uncertainty would be more tolerable for cohabitation than for marriage (Oppenheimer 2003). Especially in male breadwinner societies, the deterioration of men's employment prospects, which brings about a natural crisis of the male breadwinner model, may prompt couples to delay or forgo marriage in favor of cohabitation (Oppenheimer, Kalmijn, and Lim 1997). The temporary and reversible nature of cohabitation may offer an alternative to the commitments of marriage and a living situation that reflects uncertainties resulting from financial constraints (Gibson-Davis, Edin, and McLanahan 2005; Smock, Manning, and Porter 2005). Marriage is not necessarily rejected, but people might decide to postpone the wedding until their future prospects are clearer and men become settled in their career. While Oppenheimer's theory explicitly focuses on unstable careers, the POD narrative is usually operationalized by focusing on individual educational qualifications, and it has been generally used to explain the negative educational gradient in nonmarital childbearing (e.g., Perelli-Harris et al. 2010).

The POD develops along a trajectory that differs from the perhaps more prominent theoretical framework of the second demographic transition (hereinafter SDT; Lesthaeghe 1995; Van de Kaa 1987). The SDT explains the diffusion of new family patterns, such as cohabitation, by building on structural changes (modernization, the growth of the welfare state, the rise of higher education) and cultural changes (secularization, the rise of individualistic values, the importance of self-expression and 
self-fulfillment). Based on the theoretical considerations of the SDT, one might expect the highly educated to be at the forefront in adopting new behaviors such as cohabitation, because they may hold more liberal values and be more resistant to prevailing social stigmas.

\section{2 ... and their operationalization}

Several studies, both American and European, have found a higher share of cohabitors among the better educated (e.g., Glick and Spanier 1980; Kiernan and Lelièvre 1995; Spanier 1983), in line with the SDT theory. By contrast, other studies, especially recent ones from the US (e.g., Kennedy and Bumpass 2008; Smock and Manning 2004) and Europe (e.g., Koytcheva and Philipov 2008), have suggested an inverse association between cohabitation and education. These recent findings have often been interpreted as a symptom of the emergence of the POD (Perelli-Harris and Gerber 2011).

Education has frequently been considered a valid proxy of labor market characteristics and prospects. In recent years, in fact, individuals with lower education have had to struggle more with reduced job security and diminished wage protection than their better-educated counterparts. Nevertheless, employment uncertainty is increasingly characterizing contemporary labor markets all over Europe, irrespective of individual educational status. What is more, there is some evidence that those who are better educated are also those who are most affected by the rise in precarious forms of employment (Barbieri and Scherer 2009). Hence, to properly address the link between employment uncertainty and union formation practices, one should ideally look at the type of employment, rather than focusing solely on educational differentials or on employment/non-employment status. In recent years, a handful of studies have focused on the role of employment in union formation, also explicitly exploring the role of the different types of employment (e.g., Kurz, Steinhage, and Golsch 2005; Liefbroer 2005; Noguera, Castro Martin, and Bonmati 2005). The role of men's uncertain careers has been systematically investigated by Kalmijn (2011). Nonetheless, only a few studies have focused on the consequences of employment in the entry into both cohabitation and marriage (e.g., Bukodi 2012).

We conclude that a proper empirical test of the effects of growing employment uncertainty on the diffusion of unmarried cohabitation should ideally use fine-tuned measurements of the labor market status while also studying both genders. This paper follows these intentions by focusing on the link between job precariousness and the practice of cohabitation and marriage among women and men in Italy. We know very 
little about the Italian case, although the country represents a very interesting laboratory.

\section{The Italian setting}

\subsection{Changes in the labor market and union formation in Italy}

The process of labor market flexibilization began in Italy with the introduction of the so-called work-and-training contracts (1983-1984), followed by a weakening of the strict rules for fixed term contracts (L.56/1987), which were subsequently made increasingly more convenient for firms (L.451/1994; L.608/1996). The major step in the process of labor market deregulation/segmentation was taken in 1997 ('Treu Law', L.196/1997), while the following 'Biagi Law' (L.30/2003) gave further impulse to the spread of 'flexible' forms of employment, far less 'protective' for the worker than before, when typically unlimited jobs used to be the rule (Barbieri and Scherer 2009; Bernardi and Nazio 2005).

According to the Italian Institute of Statistics (ISTAT 2014), in 2013 about 12 million people had a permanent full-time contract, whereas self-employed people amounted to more than 5 million. The largest share of precarious contracts was represented by fixed-term (i.e., temporary) arrangements, which comprised about $13 \%$ of workers (more than 2 million people), followed by atypical contracts (i.e. projectbased or contingent work), which included almost 400,000 workers ( $1.7 \%$ of total). The spread of flexible and temporary contractual forms has been one of the fastest in Europe over the last decades, making Italy an interesting case-study. ${ }^{5}$ Through the spread of precarious work contracts, the traditional division between 'insiders' and 'outsiders' in the Italian labor market has been reinforced (Ferrera 2000). The former are typically older male workers with long-term contracts and solid guarantees in case of unemployment; the latter are mostly young, or women, with precarious jobs, low pay, and very limited (or altogether nonexistent) safety nets for periods of unemployment.

Italy also represents a relevant case study from a gender perspective because of its marked gender inequality in the labor market. Women's participation, although on the rise, is still relatively low (e.g., the 2015 employment rate for the 15-64 age range is about $47 \%$ - OECD 2016b). Even more, the diffusion of job precariousness is

\footnotetext{
${ }^{5}$ From 1993 to 2013, the share of temporary employment among dependent workers grew from 6\% to $13 \%$ in Italy, whereas the EU-28 average slightly moved from $11 \%$ to $14 \%$ (OECD $2016 \mathrm{a}$ ).
} 
gendered, with a higher proportion of women employed in professions characterized by higher precariousness and inferior job conditions, such as minor prestige, lower wages, and fewer responsibilities (Pirani and Salvini 2015).

In parallel to these labor market changes, family formation practices have also changed over the last decades in Italy. Whereas at the beginning of the 1990s, unmarried cohabitation was practiced by only about $2 \%$ of all couples, ten years later this percentage had doubled, and in the second decade of the $21^{\text {st }}$ century, more than 10 of 100 couples lived in non-marital cohabitation (Pirani and Vignoli 2016). In less than 20 years, the number of cohabiting unions has increased from about 200,000 to more than 1 million (ISTAT 2012, 2014).

\subsection{Contrasting research hypotheses}

Italian research on the possible negative consequences of precarious employment for the workers' economic situation and future career prospects is abundant (e.g., Barbieri and Scherer 2009). While there is some evidence that employment uncertainty inhibits fertility (e.g., Barbieri et al. 2015; Vignoli, Drefahl, and De Santis 2012), much less is known about its possible consequences on union formation practices (Schröder 2006). The study by Bernardi and Nazio (2005) is an exception, with the merit of investigating the role of the type of employment for both genders, but with the limit of looking at its consequences on marriage formation only. Kalmijn (2011) studied the impact of the type of employment on cohabitation and marriage in many countries, including Italy, but his analyses included only men. The retrospective data used in Bernardi and Nazio (2005) were collected in 1997, whereas those used in Kalmijn (2011) were from 1994 to 2001. Guetto et al. (2016) studied the diffusion of cohabitation in Italy using more recent micro data, but they focused on educational differentials, disregarding the role of employment uncertainty. The contemporary rise in cohabitations and in the number of temporary contracts and the importance of gender difference in male breadwinner societies (as Italy is) call for new, up-to-date insights into this matter.

Italy has a reputation in the international context in light of its latest-late transition to adulthood (Billari and Rosina 2004). The late exit from the parental home is not only attributable to labor-market and housing difficulties (Mulder and Billari 2010), but also to a culturally-rooted behavior that Massimo Livi Bacci (2001) labeled as the 'delay syndrome'. In this context, the approval of the family of origin in the choice of living in an intimate union without marriage is particularly crucial (Vignoli and Salvini 2014). Previous literature has argued that the transition to marriage is more advantageous than 
the choice of cohabitation in Italy (Di Giulio and Rosina 2007; Schröder 2006) because parents are more likely to support their adult offspring when they decide on conventional and socially accepted living arrangements such as marriage (Rosina and Fraboni 2004). The choice of informal unions might be more cost-intensive, as in this case parents tend to withdraw from supporting their adult children (Di Giulio and Rosina 2007; Schröder 2006). In addition, the Italian welfare state does not provide support for young adults, and the institutional organization of welfare is largely based on (if not delegated to) the family, which serves as the primary social safety net (Ferrera 2000).

A possible consequence of this state of affairs is that during turbulent economic times young individuals who are confronted with economic hardships tend to opt for marriage rather than cohabitation due to fear of losing the indispensable support of their family. The economic support of the family of origin is particularly important for the more disadvantaged segments of the population, who might be more inclined to opt for marriage to preserve parental economic help. Hence, we may expect cohabitation to be more popular among the better-off, who posit themselves at the forefront of the diffusion of (new) type of living arrangements. From this perspective, Italy may constitute an exception in Europe with respect to the emergence of the POD argument or Oppenheimer's thesis regarding the spread of cohabitation, and the understanding of the Italian case could be imagined as more in line with an interpretation borrowed from the SDT theory.

Nonetheless, actual data seems to challenge this vision. During the recent Great Recession, from 2007 to 2009 featuring downturns in both financial and labor market fortunes, the incidence of cohabitation increased whereas marriages decreased (Aassve et al. 2015). Along this line, we may thus advance an opposite hypothesis, namely that labor market uncertainty facilitates entry into cohabitation and inhibits entry into marriage. Incidentally, this perspective would posit the Italian case more in line with the POD interpretation than with that of the SDT. In the following sections, we aim to offer qualitative and quantitative evidence of such a complex state of affairs.

\section{Data and methods}

\subsection{Qualitative analysis}

The qualitative investigation draws on focus group interviews (FGIs). A focus group is a small group of individuals who interact with one another discussing topics centered 
on a core theme, with the discussion facilitated by a moderator. By their very nature, the goal of the FGIs is to provide information on general norms and perceptions (Morgan 1998), and not to infer individual experiences and decision-making processes. An important advantage of focus group methodology over individual in-depth interviews is that it provides the chance to study people in a more natural conversation situation. Thus, new perspectives and themes may spontaneously emerge from the interaction between participants.

The FGIs were conducted at the premises of the research design developed by the international project 'Focus on Partnerships'. Team members collaborated to create a standardized focus group guideline, which was used to direct the focus group discussions. For further information on this project, including the English version of focus group guidelines, see Perelli-Harris et al. (2014) and www.nonmarital.org. The interview guidelines included numerous questions on the (dis)advantages of living together outside marriage, motivations for marriage, and barriers to marriage. More important for this paper, the role of employment uncertainty was explicitly investigated.

We conducted FGIs in Florence from February to April 2012. Recruitment of the participants was carried out via distribution of brochures and advertisements in cinemas, universities, sport clubs, shopping malls, and so on. The participants received an incentive of 20 Euros. They were 25-40 years of age and divided into groups by gender and level of education. The higher level of education included women and men with a bachelor's or a master's degree as well as those with a post-tertiary qualification. The lower level of education included primary, vocational, lower-secondary, and uppersecondary education. In total, eight FGIs were conducted: two with women of lowmedium education, two with women with high education, two with men of low-medium education, and two with men with high education. Altogether, 58 informants participated in the study, with an average number of 7-8 participants per FGI. Overall, $59.6 \%$ of our informants were aged $25-30$, while $40.4 \%$ were aged $31-40 ; 22.2 \%$ were single, $28.9 \%$ in a relationship without coresidence, $26.3 \%$ cohabiting, and $22.6 \%$ married; $31.6 \%$ had children. In accordance with the project guidelines, focus groups were not stratified by partnership or parenthood status, as partnership histories can be inherently complicated, and it was unclear how to categorize those who experienced premarital cohabitation, separation or divorce, remarriage, and so forth.

The aim of our qualitative analysis was to explore mechanisms through which employment uncertainty might be important for the decision to cohabit or marry. The first and the third author served as independent coders; they identified all passages where motivation to marry or cohabit were discussed in the transcripts. Next, they applied a bottom-up coding procedure to this material to classify main themes 
appearing in discussions. Special attention was paid to any reference to precarious forms of employment and the categories were systematically compared to investigate the mechanisms via which employment uncertainty intertwines with relationship choices. Overall, the combination of two authors working in parallel and exchanging their findings allowed for checking the validity of interpretations.

\subsection{Quantitative analysis}

The quantitative analysis was based on retrospective data stemming from the 2009 Household Multipurpose Survey Family and Social Subjects (FSS). This survey was conducted by ISTAT on a sample of about 24,000 households, corresponding to approximately 50,000 individuals of all ages. The overall response rate of the survey was greater than $80 \%$. The 2009 FSS covered detailed information on men's and women's partnership and employment histories recorded on a monthly basis - including information on the type of contract in each employment spell. This allowed us to carry out a continuous-time event history analysis.

We looked at the transition to the first heterosexual union for men and women. The analytical sample consisted of 10,304 men and 10,675 women after selecting individuals born between 1950 and 1985; namely those especially involved in new partnership behaviors compared to older cohorts. The baseline duration was the time elapsed from the age of 16 to marriage or cohabitation, whichever came first. Following standard practice, we considered the entry into first marriage or cohabitation as two distinct processes or competing risks - i.e., the occurrence of one event removed the individual from the possibility of experiencing the other (e.g., Berrington and Diamond 2000). We censored the remaining observations at the time of the interview (November 2009). The baseline hazard had a time-varying piecewise-constant specification, with constant two-year intervals from the age of 16 to the age of 46 years, and then a single interval after age 46, when the risk of entering into the first union is very low and virtually constant.

Our core explanatory (time-varying) variable was the employment status combined with the type of employment, which we categorized into 'non-employment', 'permanent employment', 'self-employment', 'temporary employment', and 'atypical job'. Both 'temporary employment' and 'atypical job' identify precarious forms of employment, with the latter being the least protected employment condition. We controlled our estimates for a set of potential confounders. These included educational level (a time-varying variable grouped into 'in education', 'primary education', 'upper- 
secondary education', 'tertiary education') and calendar time. The purpose of the latter time-varying variable was to reflect key appointments in the flexibilization of the Italian labor market: the entry into force of the Treu Law (1997) and the Biagi Law (2003).

We adjusted the estimates by intra-group correlation (at the level of the region). This approach specifies that observations are independent across clusters (i.e. regions) but not within clusters. In this way we acknowledge that there may be important similarities in patterns of union formation and their correlates among respondents living in the same region. In addition, we included a covariate for the area of residence (divided into three categories: 'North', 'Center', and 'South/Islands') in the final model specification. $^{6}$

Descriptive statistics on the composition of the sample are reported in the Appendix (Tables A1-2). It is worth noting that among those who were employed and completed their education, individuals with tertiary education were those more involved in atypical jobs and temporary employment $(21.2 \%$ of higher educated women and $13.9 \%$ of higher educated men), and less involved in permanent employment $(61.7 \%$ and $57.5 \%$, respectively). ${ }^{7}$ At the same time, a greater participation of women in fixedterm contracts (both atypical and temporary) among workers emerged clearly, with $15.8 \%$ of women versus $10.2 \%$ of men.

\section{Results}

\subsection{Qualitative findings}

In this section, we present exploratory insights from the qualitative analysis. We explored the content of the FGIs to see what kinds of references are made when the respondents discuss the role of employment uncertainty underlying their perception about cohabitation and marriage. According to our findings, employment instability and job precariousness that characterize contemporary labor markets increase the uncertainty and intensify the difficulties experienced by young people in their transition to adulthood, when they start their employment careers, try to strengthen their economic

\footnotetext{
${ }^{6}$ The area of residence was collected at the time of the interview. However, it is relatively trouble-free to use the macro-area of residence as a time-constant covariate because Italian internal mobility has been low over recent decades and mainly restricted to short distances only (Reynaud and Conti 2011).

${ }^{7}$ Given that employment, educational attainment, and partnership are time-varying covariates, we considered the condition in which each individual was in the last spell (namely, at the time of cohabitation or marriage, or at the interview date).
} 
position, and begin to consider family formation. Informants treated their position on the labor market as an urgent issue. There was a generalized need for greater stability in the labor market, as this male participant pointed out:

"I graduated, but I'm currently unemployed, I even accepted to carry out several unpaid training periods ... we are this new generation that lives hoping in God, holding only temporary contracts: Everything is postponed until a moment of stability in life..." (FG 4; man, high education)

When partners have jobs of unlimited duration, they can get married. As one informant stated, "it is important to have at least one permanent job, at least one fixed point in life!" (FG 8; man, low education). Couples starting cohabitation are able to support themselves economically, but decide to take a more 'stable', 'permanent' commitment like marriage as soon as a 'permanent' employment is found. An informant put this very clearly:

"The right moment to get married arrives with a stable job! I'm 32, but I continue to get one-year contracts only, so with my partner we say: we'll get married as soon as we have a secure point in our life. In fact, I don't even know if I'll still live in Florence next year ... and this is the fault of my job!" (FG 1; woman, high education)

The spread of job precariousness seems to affect the decision to marry also by acting as a financial barrier to the wedding ceremony. The traditional ceremony was often imagined as quite expensive, and this was perceived as a direct cause of postponement of marriage until the couple is economically 'ready'. Some people reported that the cost of the ceremony depends on what a couple expects: One can have a small or large ceremony. Nevertheless, the general feeling was that even a small ceremony requires considerable financial investment:

"Getting married is expensive! I married in April at a small ceremony, with only few people and simple catering at my place. But we still had to spend quite some money, and not everybody can afford it." (FG 1; woman, high education) 
On the other hand, the same reasons that are perceived as inhibitors to marriage were also mentioned among the major motivations beyond the choice to cohabit. The following quote is representative of this state of affairs:

"People cohabit due to money shortages, definitely, and due to precarious working conditions. These reasons are more important than anything else!" (FG 5; woman, low education).

Uncertainty on the labor market was associated with uncertainty in private life, where cohabitation is preferred to a more 'stable' marriage. In fact, cohabiting is easier to disrupt than marriage and may be seen as an opportunity to test the functioning of a relationship, "Cohabitation is a sort of test" (FG 4; men, low education). Especially for some men, cohabitation was attractive because this condition meets the desire to keep some personal independence while marriage represents a frightening ultimate commitment. For example, one participant argued:

"With cohabitation there are no problems if you decide to split, you just need to say 'thanks and goodbye', and that's it!" (FG 3; man, high education)

When both partners have reached a permanent employment status, then the 'right time' to reach a permanent status also in their relationship seems to follow soon after, in a sort of 'time-squeeze'. The following quote is representative of this situation:

"Stable job for him, stable job for myself, 4 months later we got married, 9 months later I was pregnant... we were ready! I mean, finally we have some protection, we have some rights... we can go!'” (FG 1; woman, high education)

In short, many voices claimed that the 'right time' to get married is when a stable job is obtained, for at least one member of the couple (and preferably the male partner). As one informant clearly concluded:

"If you have a permanent job, then you can also make a permanent choice!" (FG 2; woman, high education) 
In all, informants believed that economic circumstances matter for marriage. First, having a stable contract was commonly perceived as a prerequisite for marriage, backed by the consideration that marriage requires economic security. Second, participants viewed the shortage of 'enough money' - using a term borrowed from Smock et al. (2005) - to afford a 'proper' wedding as a barrier to marriage. Based on the qualitative section of our study, we can therefore envisage that employment uncertainty is positively associated with entry into cohabitation and negatively with entry into marriage. This perspective, in line with the arguments advanced by the proponents of the POD approach and Oppenheimer's thesis, hardly reconciles with former interpretations of the Italian setting, calling for a formal test of the qualitative evidence. In the following quantitative analysis, we examine to what extent this new mechanism, suggested by the qualitative section of the study, is maintained at the population level.

\subsection{Quantitative findings}

Figure 1a-b displays the hazards of entry into marriage and cohabitation for Italian women and men, controlling for the age and the type of contract. Looking at age patterns, the highest risks of entry into marriage are observed at younger ages compared to those of entry into cohabitation, for both men and women. The relative risks for entry into marriage are at their lowest levels when women are experiencing the most unstable forms of employment - the aforementioned atypical jobs. On the other hand, women in atypical jobs are also those characterized by the highest relative risks of entering cohabitation. Thus, the hypothesis developed through the qualitative analysis - i.e. that marriage is linked to employment stability, while cohabitation is linked to employment uncertainty - seems to be confirmed for Italian women.

A different situation is observed among Italian men. The lowest relative risks of entering marriage are found for the non-employed, followed by men faced with precarious work contracts (temporary and atypical). Men's relative risks of entering cohabitation do not significantly differ by their employment status: Any type of employment is associated with a higher cohabitation risk compared to non-employment. Although employment uncertainty jeopardizes marriage among employed men, the largest contrast is, however, between any work and no work at all, which supports a basic male breadwinner argument. In all, any type of employment fosters men's entry into union. 
Figure 1: Timing of entry into marriage and cohabitation by employment status in Italy for (a) women and (b) men. Results of a piecewiseconstant event history competing risk model.

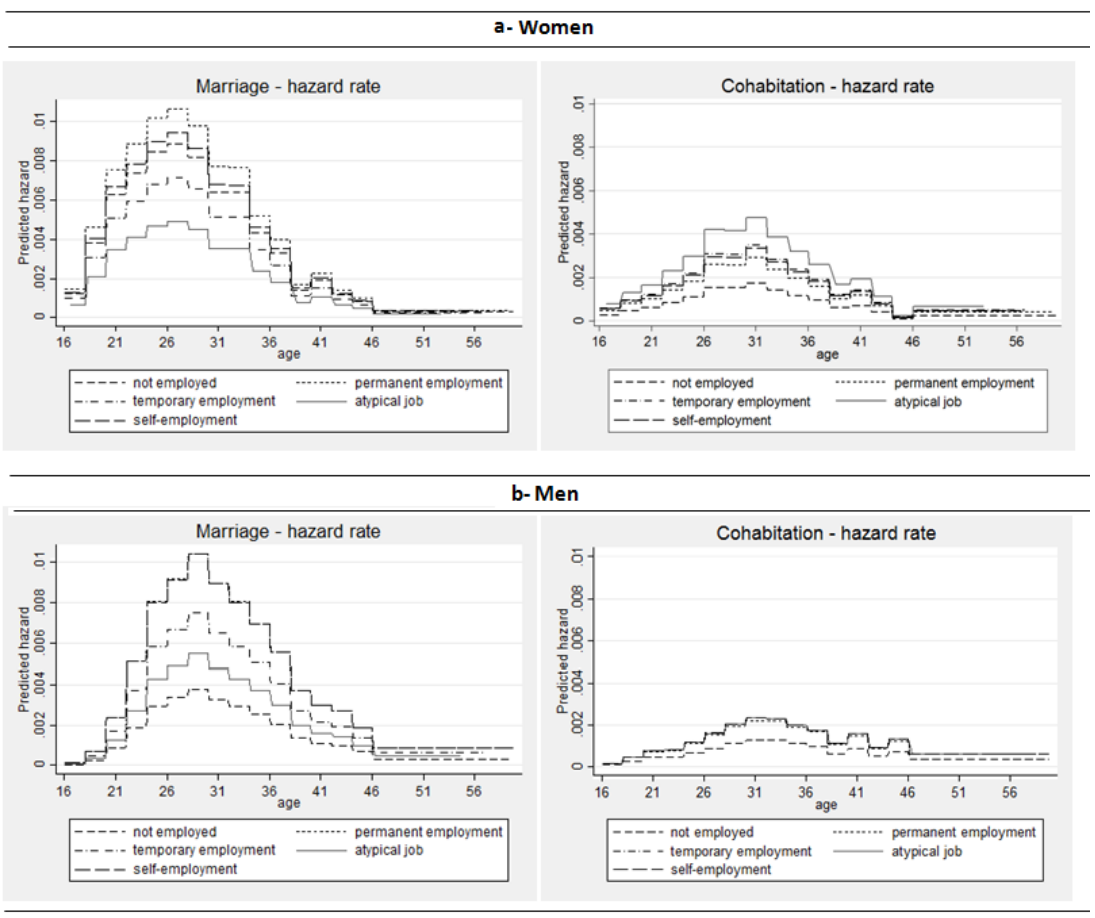

Source: Our elaborations on FSS 2009 data.

Note: Estimates are adjusted for intra-cluster (i.e. regional) correlation.

In the next step, we included the educational attainment, area of residence, and calendar time in our models (Table 1 and 2). Confirming previous bivariate evidence, women holding an atypical contract display a higher relative risk of entering cohabitation than those who have a permanent employment, net of all other confounders (Table 1). We also note that women with temporary jobs are characterized by significantly lower hazards of marriage. The lowest relative risks to entry into marriage of women with atypical jobs (depicted in Figure 1) is no longer significant after controlling our estimates for educational attainment, area of residence, and calendar time. This effect is mediated by the calendar period, which reflects the 
growing employment uncertainty over recent years. ${ }^{8}$ Nevertheless, the lower relative risk of entry into marriage for women holding fixed-term contracts compared to those who are permanently employed remains substantial.

Looking at men (Table 2), the results can be read in a rather similar fashion. We found that those experiencing precarious employment conditions (fixed-term employment and atypical contractual forms) are significantly less likely to enter marriage than men with permanent employment, even if the lowest risk of marrying belongs to non-employed men. Among employed men, the relative risk to enter into marriage decreases as employment precariousness increases. In parallel, the lowest hazards of cohabitation can be found among non-employed men, while being employed increases the risks of cohabitation. ${ }^{9}$ Again, the role of job precariousness seems to be partly mitigated by the calendar time.

Overall, our quantitative findings support the hypothesis advanced from the previous qualitative exploration: We showed that labor market uncertainty promotes entry into cohabitation. Even more, employment uncertainty affects the entry into marriage, reducing the marriage risk for those holding atypical contractual forms, or fixed-term employments, compared to those who have a permanent job.

The effects of the control covariates go in the expected direction, providing us with an indirect validation of the statistical model itself. Relative risks of entering cohabitation are higher (and conversely lower in the case of marriage) in Central and Northern Italian regions. The risk of entering cohabitation increases with the progression of the calendar time (that embodies the progressive flexibilization of the labor market), while the risk of getting married decreases. Interestingly, our outcomes illustrate very few differentials by educational level. Differences by educational qualification for entry into cohabitation did not emerge from our models even excluding the employment status (results not shown but available upon request). These outcomes confirm our opinion that researchers should not limit their investigation to the mere role of education when they seek to test the function of economic factors on patterns of union formation.

\footnotetext{
${ }^{8}$ Accordingly, a model where we excluded only calendar time (not shown here; available upon request) revealed that the impact of an atypical working condition had a significant detrimental effect on marriage risks.

${ }^{9}$ Choosing the non-employed condition as the reference category, the relative risk of entering cohabitation increases significantly as job precariousness increases for both men and women.
} 
Table 1: Relative risks of entry into cohabitation or marriage. Piecewise constant, competing risk exponential model; Italy, women

\begin{tabular}{|c|c|c|c|c|c|c|}
\hline \multirow[b]{2}{*}{ Covariates } & \multicolumn{3}{|c|}{ Entry into marriage } & \multicolumn{3}{|c|}{ Entry into cohabitation } \\
\hline & $\begin{array}{c}\text { hazard } \\
\text { ratio }\end{array}$ & $\begin{array}{c}\text { standard } \\
\text { error }\end{array}$ & & $\begin{array}{c}\text { hazard } \\
\text { ratio }\end{array}$ & $\begin{array}{c}\text { standard } \\
\text { error }\end{array}$ & \\
\hline \multicolumn{7}{|l|}{ Employment } \\
\hline permanent employment & 1.000 & & & 1.000 & & \\
\hline not employed & 1.035 & 0.040 & & 0.861 & 0.095 & \\
\hline temporary employment & 0.768 & 0.043 & $* * *$ & 1.215 & 0.192 & \\
\hline atypical job & 0.779 & 0.124 & & 1.447 & 0.281 & * \\
\hline self-employment & 0.947 & 0.053 & & 1.161 & 0.098 & * \\
\hline \multicolumn{7}{|l|}{ Educational attainment } \\
\hline in education & 0.316 & 0.018 & $* * *$ & 0.631 & 0.075 & *** \\
\hline primary education & 1.301 & 0.047 & $* * *$ & 1.028 & 0.078 & \\
\hline tertiary education & 1.097 & 0.040 & $* *$ & 1.184 & 0.121 & \\
\hline \multicolumn{7}{|l|}{ Macro-area of residence } \\
\hline North of Italy & 1.000 & & & 1.000 & & \\
\hline Center of Italy & 1.095 & 0.057 & * & 0.765 & 0.097 & $* *$ \\
\hline South of Italy & 1.132 & 0.056 & $* *$ & 0.306 & 0.062 & *** \\
\hline \multicolumn{7}{|l|}{ Calendar time } \\
\hline before 1994 & 1.000 & & & 1.000 & & \\
\hline 1994-1997 & 0.560 & 0.026 & $* * *$ & 1.589 & 0.164 & $* * *$ \\
\hline 1997-2003 & 0.563 & 0.025 & $* * *$ & 2.397 & 0.197 & $* * *$ \\
\hline 2003-2006 & 0.512 & 0.030 & $* * *$ & 3.520 & 0.356 & $* * *$ \\
\hline after 2006 & 0.445 & 0.035 & $* * *$ & 2.253 & 0.307 & $* * *$ \\
\hline
\end{tabular}

Note: Estimates are adjusted for intra-cluster (i.e. regional) correlation. Piecewise constant specification for age classes (not shown): constant two-year intervals from the age of 16 to the age of 46 years, and then a single interval after age 46 . 
Vignoli, Tocchioni \& Salvini: Insights into the role of job precariousness in union formation in Italy

Table 2: Relative risks of entry into cohabitation or marriage. Piecewise constant, competing risk exponential model; Italy, men.

\begin{tabular}{|c|c|c|c|c|c|c|}
\hline \multirow[b]{2}{*}{ Covariates } & \multicolumn{3}{|c|}{ Entry into marriage } & \multicolumn{3}{|c|}{ Entry into cohabitation } \\
\hline & $\begin{array}{c}\text { hazard } \\
\text { ratio }\end{array}$ & $\begin{array}{c}\text { standard } \\
\text { error }\end{array}$ & & $\begin{array}{c}\text { hazard } \\
\text { ratio }\end{array}$ & $\begin{array}{c}\text { standard } \\
\text { error }\end{array}$ & \\
\hline \multicolumn{7}{|l|}{ Employment } \\
\hline permanent employment & 1.000 & & & 1.000 & & \\
\hline not employed & 0.389 & 0.025 & $* * *$ & 0.676 & 0.054 & $* * *$ \\
\hline temporary employment & 0.727 & 0.038 & $* * *$ & 1.142 & 0.110 & \\
\hline atypical job & 0.657 & 0.124 & $* *$ & 0.973 & 0.265 & \\
\hline self-employment & 0.972 & 0.034 & & 1.105 & 0.090 & \\
\hline \multicolumn{7}{|l|}{ Educational attainment } \\
\hline upper-secondary education & 1.000 & & & 1.000 & & \\
\hline in education & 0.657 & 0.021 & $* * *$ & 0.993 & 0.110 & \\
\hline primary education & 1.125 & 0.045 & $* * *$ & 1.039 & 0.084 & \\
\hline tertiary education & 1.061 & 0.066 & & 1.210 & 0.103 & $* *$ \\
\hline \multicolumn{7}{|l|}{ Macro-area of residence } \\
\hline North of Italy & 1.000 & & & 1.000 & & \\
\hline Center of Italy & 1.129 & 0.051 & $* * *$ & 0.803 & 0.108 & \\
\hline South of Italy & 1.384 & 0.090 & $* * *$ & 0.363 & 0.064 & $* * *$ \\
\hline \multicolumn{7}{|l|}{ Calendar time } \\
\hline before 1994 & 1.000 & & & 1.000 & & \\
\hline 1994-1997 & 0.564 & 0.033 & $* * *$ & 1.581 & 0.152 & $* * *$ \\
\hline 1997-2003 & 0.526 & 0.027 & $* * *$ & 2.436 & 0.150 & $* * *$ \\
\hline 2003-2006 & 0.461 & 0.023 & $* * *$ & 3.063 & 0.383 & $* * *$ \\
\hline after 2006 & 0.368 & 0.024 & $* * *$ & 2.194 & 0.115 & $* * *$ \\
\hline
\end{tabular}

Note: Estimates are adjusted for intra-cluster (i.e. regional) correlation. Piecewise constant specification for age classes (not shown): constant two-year intervals from the age of 16 to the age of 46 years, and then a single interval after age 46 .

\section{Concluding discussion}

In the social landscape of Europe, life in the labor market sphere has recently become increasingly uncertain (Blossfeld et al. 2005; Kohler, Billari, and Ortega 2002; Kreyenfeld, Andersson, and Pailhe 2012; Sobotka and Toulemon 2008; Vignoli, 
Drefahl, and De Santis 2012; Vignoli, Rinesi, and Mussino 2013). In our study, we have addressed the link between employment uncertainty and union formation practices in Italy, a country largely under-studied in this respect. A first qualitative exploration allowed us to advance the hypothesis - new for the Italian setting - that labor market uncertainty favors cohabitation while employment stability facilitates marriage. A subsequent quantitative analysis provided strong support for this hypothesis at the population level.

Overall, our findings support the idea that cohabitation - in contrast to marriage is more compatible with the new demands of today's labor market, such as mobility, flexibility, and the resulting uncertainty. According to this view, cohabitation appears to be an adequate alternative to marriage, as it allows for living together without taking on the long-term responsibilities that are usually associated with an enduring union. Our qualitative and quantitative findings thus contribute to our understanding of the implications of recent labor market changes on family formation practices. Given the contemporary economic fluctuations in Europe, we expect that labor market uncertainty will continue to represent a potent factor shaping the choice of the type of union in the years to come.

In addition, our findings add to Italian literature on union formation. Traditional calculations make it feasible to expect that labor market uncertainty will promote entry into marriage rather than the transition into cohabitation because parents are more likely to support their adult offspring when they decide to marry, and during turbulent economic times parental support is especially important. In contrast with these predictions, our mixed-method findings instead suggest the emergence of a POD as a driver of the spread of cohabitation. Young Italians faced with blocked opportunities might prefer cohabitation to marriage due to its lower level of commitment; alternatively, they might decide to postpone marriage until their outlook on life is more optimistic (e.g., Oppenheimer 1988).

These reflections are especially valid for women, and for employed men. Among men, in fact, the crucial source of variation in family formation practices is having a job in the first place. A rather difficult pattern seems to emerge for non-employed men: Not only do they not work, but they also display the smallest hazards of union formation, so that the disadvantage spreads from the economic sphere to other life domains as well. This finding seems to be in line with the old-fashioned, but still existing, male breadwinner interpretation of Italian society. When women are the main caregivers and men act primarily as household providers, the economic well-being of the household depends mainly on the market performance of the man. Nonetheless, because - contrary to women - the great majority of men are employed, the spread of employment 
uncertainty also plays an important role. Despite a gendered diffusion of job precariousness in Italy, young men are now also confronted with a worsening of their economic situation, thus demolishing the 'first pillar' of Italian families (i.e., a male partner with a stable and well-paid job).

Despite the rich and large-scale retrospective survey used in the quantitative section of the study, our research design has some limitations. First, we could not differentiate non-employment spells between unemployment and inactivity. This may be problematic especially for women, for whom the distinction between being unemployed and being a homemaker is crucial. Second, we had to code 'selfemployment' as a broad, distinct category. Nevertheless, within this condition classical self-employment arrangements coexist with new situations where people are forced to opt for self-employment as an alternative to a permanent contract. In this vein, Adsera (2004) claimed that the emergence of self-employment in Southern Europe may be seen as a symptom of rising employment uncertainty. Finally, we could not cover the whole spectrum of possible links between employment uncertainty and relationship status. Our data offered us the possibility to use retrospective information only on coresident partnership histories, thus excluding the possibility to explore the link between employment uncertainty and 'living-apart-together' (LAT) relationships over the life course. Nonetheless, economic and social uncertainty may delay the entry into a stable relationship, especially for men. LAT relationships in Italy may also act as a substitute for cohabitation because of the Italian latest-late transition to adulthood and tradition of marriage (Billari et al. 2008; Régnier-Loilier and Vignoli 2014). To be sure, currently there are no Italian data with retrospective/prospective information on relationship (including LAT) histories coupled with employment careers.

In all, our study provides fresh insights into the role of job precariousness in family formation practices. For many years, the dominant view of the spreading of cohabitation in Europe was inspired by the SDT narrative. Only recently has a different explanation, derived partly from U.S. qualitative literature (e.g., Gibson-Davis, Edin, and McLanahan 2005; Smock and Manning 2004), begun to gain ground (Perelli-Harris et al. 2010; Perelli-Harris and Gerber 2011). Our findings, in line with the POD perspective, see economic uncertainty as a potent driving force of union formation dynamics also in Italy. Previous studies have focused on the role of education as an indicator of economic disadvantage, and stressed its influence on fertility and family formation practices. We suggest that other factors, such as the role of job precariousness, may be equally - or even more - crucial. 


\section{Acknowledgments}

Funding for the qualitative section of the study comes from Brienna Perelli-Harris's Starting Grant CHILDCOHAB (ERC-StG-2011-263794) funded by the European Research Council. The authors also acknowledge the financial support provided by the research project 'Families and Well-being in Italy: Dynamics and Relationships' [Famiglie e benessere in Italia: Dinamiche e relazioni], financed by the University of Florence (PI: Daniele Vignoli). Elena Pirani is gratefully acknowledged for her valuable comments on previous versions of the manuscript. 


\section{References}

Aassve, A., Cottini, E., Fraboni, R., and Vitali, A. (2015). Giovani e formazione delle unioni. In: De Rose, A. and Strozza, S. (eds.). Rapporto sulla popolazione. L'Italia nella crisi economica. Bologna: Il Mulino: 33-62.

Adsera, A. (2004). Changing fertility rates in developed countries. The impact of labor market institutions. Journal of Population Economics 17(1): 17-43. doi:10.1007/ s00148-003-0166-x.

Barbieri, P. and Scherer, S. (2009). Labour market flexibilisation and its consequences in Italy. European Sociological Review 25(6): 677-692. doi:10.1093/esr/jcp009.

Barbieri, P., Bozzon, R., Scherer, S., Grotti, R., and Lugo, M. (2015). The rise of a Latin model? Family and fertility consequences of employment instability in Italy and Spain. European Societies 17(4): 423-446. doi:10.1080/14616696. 2015.1064147.

Bauman, Z. (2005). Liquid life. Cambridge: Polity Press.

Bernardi, F. and Nazio, T. (2005). Globalization and the transition to adulthood in Italy. In: Blossfeld, H.-P., Klizing, E., Mills, M., and Kurz, K. (eds.). Globalization, uncertainty and youth in society. London: Routledge: 349-374.

Berrington, A. and Diamond, I. (2000). Marriage or cohabitation: A competing risks analysis of first-partnership formation among the 1958 British birth cohort. Journal of the Royal Statistical Society Series a - Statistics in Society 163(2): 127-151. doi:10.1111/1467-985X.00162.

Billari, F.C. and Rosina, A. (2004). Italian low fertility between economic constraints and changing values. Genus 60(1): 71-87.

Billari, F.C., Rosina, A., Ranaldi, R., and Clelia Romano, M. (2008). Young adults living apart and together (LAT) with parents: A three-level analysis of the Italian case. Regional Studies 42(5): 625-639. doi:10.1080/00343400701543173.

Billy, J.O.G. and Moore, D.E. (1992). A multilevel analysis of marital and nonmarital fertility in the United-States. Social Forces 70(4): 977-1011. doi:10.1093/sf/70. 4.977.

Blossfeld, H.-P., Klijzing, E., Mills, M., and Kurz, K. (2005). Globalization, uncertainty and youth in society. London: Routledge. 
Blossfeld, H.-P. and Hofmeister, H. (2006). Globalization, uncertainty and women's careers: An international comparison. Cheltenham: Edward Elgar.

Blossfeld, H.-P., Mills, M., and Bernardi, F. (2006). Globalization, uncertainty and men's careers: An international comparison. Cheltenham: Edward Elgar.

Bukodi, E. (2012). The relationship between work history and partnership formation in cohorts of British men born in 1958 and 1970. Population Studies 66(2): 123145. doi: $10.1080 / 00324728.2012 .656853$.

Caroli, E. and Godard, M. (2013). Does job insecurity deteriorate health? A causal approach for Europe. Paris: Paris School of Economics.

Di Giulio, P. and Rosina, A. (2007). Intergenerational family ties and the diffusion of cohabitation in Italy. Demographic Research 16(14): 441-468. doi:10.4054/ DemRes.2007.16.14.

Ferrera, M. (2000). Reconstructing the welfare state in Southern Europe. In: Kuhnle, S. (ed.). Survival of the European welfare state. London: Routledge: 166-181.

Friedman, D., Hechter, M., and Kanazawa, S. (1994). A theory of the value of children. Demography 31(3): 375-401. doi:10.2307/2061749.

Gibson-Davis, C.M., Edin, K., and McLanahan, S. (2005). High hopes but even higher expectations: The retreat from marriage among low-income couples. Journal of Marriage and Family 67(5): 1301-1312. doi:10.1111/j.1741-3737.2005.00 218.x.

Glick, P.C. and Spanier, G.B. (1980). Married and unmarried cohabitation in the United-States. Journal of Marriage and the Family 42(1): 19-30. doi:10.2307/ 351930 .

Guetto, R., Mancosu, M., Scherer, S., and Torricelli, G. (2016). The spreading of cohabitation as a diffusion process: Evidence from Italy. European Journal of Population: 1-26. doi:10.1007/s10680-016-9380-6.

ISTAT (2012). Rapporto annuale 2012. Rome: ISTAT.

ISTAT (2014). Rapporto annuale 2014. Rome: ISTAT.

Kalmijn, M. (2011). The Influence of men's income and employment on marriage and cohabitation: Testing Oppenheimer's theory in Europe. European Journal of Population 27(3): 269-293. doi:10.1007/s10680-011-9238-x. 
Kennedy, S. and Bumpass, L. (2008). Cohabitation and children's living arrangements: New estimates from the United States. Demographic Research 19(47): 16631692. doi:10.4054/DemRes.2008.19.47.

Kiernan, K.E. and Lelièvre, E. (1995). Great Britain. In: Blossfeld, H.-P. (ed.). The new role of women: Family formation in modern societies. Oxford: Westview Press: 126-149.

Kohler, H.P., Billari, F.C., and Ortega, J.A. (2002). The emergence of lowest-low fertility in Europe during the 1990s. Population and Development Review 28(4): 641-680. doi:10.1111/j.1728-4457.2002.00641.x.

Koytcheva, E. and Philipov, D. (2008). Bulgaria: Ethnic differentials in rapidly declining fertility. Demographic Research 19(13): 361-401. doi:10.4054/Dem Res.2008.19.13.

Kreyenfeld, M., Andersson, G., and Pailhe, A. (2012). Economic uncertainty and family dynamics in Europe: Introduction. Demographic Research 27(28): 835-852. doi:10.4054/DemRes.2012.27.28.

Kurz, K., Steinhage, N., and Golsch, K. (2005). Case study Germany. Global competition, uncertainty and the transition to adulthood. In: Blossfeld, H.-P., Klijzing, E., Mills, M., and Kurz, K. (eds.). Globalization, uncertainty and youth in society. London: Routledge: 51-82.

Lesthaeghe, R. (1995). The second demographic transition in western countries: An interpretation. In: Mason, K.O. and Jensen, A.M. (eds.). Gender \& family change in industrialized countries. Oxford: Clarendon Press: 17-62.

Liefbroer, A.C. (2005). Transition from youth to adulthood in the Netherlands. In: Blossfeld, H.-P., Klijzing, E., Mills, M., and Kurz, K. (eds.). Globalization, uncertainty and youth in society. London: Routledge: 83-104.

Livi Bacci, M. (2001). Too few children and too much family. Daedalus 130(3): 139155.

Livi Bacci, M. (2008). Avanti giovani, alla riscossa. Come uscire dalla crisi giovanile. Bologna: Il Mulino.

Mills, M. and Blossfeld, H.-P. (2013). The second demographic transition meets globalisation: a comprehensive theory to understand changes in family formation in an era of rising uncertainty. In: Evans, A. and Baxter, J. (eds.). Negotiating 
the life course. Stability and change in life pathways. New York: Springer: 9-33. doi:10.1007/978-90-481-8912-0_2.

Morgan, D.L. (1998). Practical strategies for combining qualitative and quantitative methods: Applications to health research. Qualitative Health Research 8(3): 362-376. doi:10.1177/104973239800800307.

Mulder, B. and Billari, F.C. (2010). Home-ownership regimes and low fertility. Housing Studies 25(4): 527-541. doi:10.1080/02673031003711469.

Noguera, C.S., Castro Martin, T., and Bonmati, A.S. (2005). The Spanish case. The effect of the globalization process on the transition to adulthood. In: Blossfeld, H.-P., Klijzing, E., Mills, M., and Kurz, K. (eds.). Globalization, uncertainty and youth in society. London: Routledge: 375-402.

OECD (2002). Employment outlook. Paris: OECD. doi:10.1787/empl_outlook-2002-en.

OECD (2016a). Temporary employment (indicator) [electronic resource]. Paris: OECD. https://data.oecd.org/emp/temporary-employment.htm\#indicator-chart.

OECD (2016b). OECD.Stat. Short-term labour market statistics [electronic resource]. Paris: OECD. http://stats.oecd.org/Index.aspx?DataSetCode=STLABOUR\#

Oppenheimer, V.K. (1988). A theory of marriage timing: Assortative mating under varying degrees of uncertainty. American Journal of Sociology 94(3): 563-591.

Oppenheimer, V.K., Kalmijn, M., and Lim, N. (1997). Men's career development and marriage timing during a period of rising inequality. Demography 34(3): 311330. doi: $10.2307 / 3038286$.

Oppenheimer, V.K. (2003). Cohabiting and marriage during young men's careerdevelopment process. Demography 40(1): 127-149. doi:10.2307/3180815.

Perelli-Harris, B., Sigle-Rushton, W., Kreyenfeld, M., Lappegard, T., Keizer, R., and Berghammer, C. (2010). The educational gradient of childbearing within cohabitation in Europe. Population and Development Review 36(4): 775-801. doi:10.1111/j.1728-4457.2010.00357.x.

Perelli-Harris, B. and Gerber, T.P. (2011). Nonmarital childbearing in Russia: Second Demographic Transition or pattern of disadvantage? Demography 48(1): 317342. doi:10.1007/s13524-010-0001-4. 
Perelli-Harris, B., Mynarska, M., Berrington, A., Evans, A., Berghammer, C., Isupova, O., Keizer, R., Klärner, A., Lappegård, T., and Vignoli, D. (2014). Towards a new understanding of cohabitation: Insights from focus group research across Europe and Australia. Demographic Research 31(34): 1043-1078. doi:10.4054/ DemRes.2014.31.34.

Pirani, E. and Salvini, S. (2015). Is temporary employment damaging to health? A longitudinal study on Italian workers. Social Science \& Medicine 124: 121-131. doi:10.1016/j.socscimed.2014.11.033.

Pirani, E. and Vignoli, D. (2016). Changes in the satisfaction of cohabitors relative to spouses over time. Journal of Marriage and Family 78(3): 598-609. doi:10.11 11/jomf.12287.

Régnier-Loilier, A. and Vignoli, D. (2014). Similar incidence, different nature? Characteristics of living apart together relationships in France and Italy. Florence: DiSIA, University of Florence (DiSIA Working Paper).

Reynaud, C. and Conti, C. (2011). Mobilità della popolazione, immigrazione e presenza straniera. In: Salvini, S. and De Rose, A. (eds.). Rapporto sulla popolazione. L'Italia a 150 anni dall'Unità. Bologna: Il Mulino: 97-118.

Rosina, A. and Fraboni, R. (2004). Is marriage losing its centrality in Italy? Demographic Research 11(6): 149-172. doi:10.4054/DemRes.2004.11.6.

Sansonetti, S. (2009). Social indicators of secularisation in Italy. In: Kosmin, B.A. and Keysar, A. (eds.). Secularism, women and the state: The mediterranean world in the 21st century. Hartford: Institute for the Study of Secularism in Society and Culture: $137-154$.

Schröder, C. (2006). Cohabitation in Italy: Do parents matter? Genus 62(3/4): 53-85.

Smock, P.J. and Manning, W.D. (2004). Living together unmarried in the United States: Demographic perspectives and implications for family policy. Law \& Policy 26(1): 87-117. doi:10.1111/j.0265-8240.2004.00164.x.

Smock, P.J., Manning, W.D., and Porter, M. (2005). 'Everything's there except money': How money shapes decisions to marry among cohabitors. Journal of Marriage and Family 67(3): 680-696. doi:10.1111/j.1741-3737.2005.00162.x. 
Sobotka, T. and Toulemon, L. (2008). Changing family and partnership behaviour: Common trends and persistent diversity across Europe. Demographic Research 19(6): 85-138. doi:10.4054/DemRes.2008.19.6.

Spanier, G.B. (1983). Married and unmarried cohabitation in the United States: 1980. Journal of Marriage and the Family 45(2): 277-288. doi:10.2307/351507.

Standing, G. (2011). The precariat: The new dangerous class. London: Bloomsbury.

Van de Kaa, D.J. (1987). Europe's second demographic transition. Population Bulletin 42(1): $1-57$.

Vignoli, D., Drefahl, S., and De Santis, G. (2012). Whose job instability affects the likelihood of becoming a parent in Italy? A tale of two partners. Demographic Research 26(2): 39-62. doi:10.4054/DemRes.2012.26.2.

Vignoli, D., Rinesi, F., and Mussino, E. (2013). A home to plan the first child? Fertility Intentions and Housing Conditions in Italy. Population Space and Place 19(1): 60-71. doi:10.1002/psp.1716.

Vignoli, D. and Salvini, S. (2014). Religion and union formation in Italy: Catholic precepts, social pressure, and tradition. Demographic Research 31(35): 10791105. doi:10.4054/DemRes.2014.31.35. 
Vignoli, Tocchioni \& Salvini: Insights into the role of job precariousness in union formation in Italy

\section{Appendix}

Table A-1: Exposures (person-months) and occurrences; Italy, women

\begin{tabular}{|c|c|c|c|c|c|c|}
\hline \multirow[b]{2}{*}{ Covariates } & \multicolumn{2}{|l|}{ Exposure } & \multicolumn{2}{|c|}{$\begin{array}{l}\text { Marriage } \\
\text { occurrence } \\
\end{array}$} & \multirow{2}{*}{$\begin{array}{c}\text { Cohabitation } \\
\text { occurrence } \\
\text { absolute } \\
\text { value }\end{array}$} & \multirow[b]{2}{*}{$\%$} \\
\hline & $\begin{array}{c}\text { absolute } \\
\text { value }\end{array}$ & $\%$ & $\begin{array}{c}\text { absolute } \\
\text { value }\end{array}$ & $\%$ & & \\
\hline \multicolumn{7}{|l|}{ Employment } \\
\hline not employed & 828,002 & 62.23 & 3.934 & 54.43 & 561 & 39.93 \\
\hline permanent employment & 363,692 & 27.33 & 2.537 & 35.10 & 566 & 40.28 \\
\hline temporary employment & 73,687 & 5.54 & 363 & 5.02 & 138 & 9.82 \\
\hline atypical job & 9,920 & 0.75 & 37 & 0.51 & 31 & 2.21 \\
\hline self-employment & 55,316 & 4.16 & 356 & 4.93 & 109 & 7.76 \\
\hline \multicolumn{7}{|l|}{ Educational attainment } \\
\hline upper-secondary & 396,946 & 29.83 & 2.800 & 38.74 & 574 & 40.85 \\
\hline in education & 451,108 & 33.90 & 705 & 9.76 & 263 & 18.72 \\
\hline primary education & 407,911 & 30.66 & 3.189 & 44.13 & 388 & 27.62 \\
\hline tertiary education & 74,652 & 5.61 & 533 & 7.38 & 180 & 12.81 \\
\hline \multicolumn{7}{|l|}{ Macro-area of residence } \\
\hline North of Italy & 551,577 & 41.45 & 2.815 & 38.95 & 866 & 61.64 \\
\hline Center of Italy & 234,738 & 17.64 & 1.280 & 17.71 & 281 & 20.00 \\
\hline South of Italy & 544,302 & 40.91 & 3.132 & 43.34 & 258 & 18.36 \\
\hline \multicolumn{7}{|l|}{ Calendar time } \\
\hline before 1994 & 761,837 & 57.25 & 4.976 & 68.85 & 446 & 31.74 \\
\hline 1994-1997 & 125,398 & 9.42 & 520 & 7.20 & 137 & 9.75 \\
\hline 1997-2003 & 240,510 & 18.08 & 980 & 13.56 & 393 & 27.97 \\
\hline 2003-2006 & 103,553 & 7.78 & 405 & 5.60 & 261 & 18.58 \\
\hline after 2006 & 99,319 & 7.46 & 346 & 4.79 & 168 & 11.96 \\
\hline
\end{tabular}


Table A-2: Exposures (person-months) and occurrences; Italy, men

\begin{tabular}{|c|c|c|c|c|c|c|}
\hline \multirow[b]{2}{*}{ Covariates } & \multicolumn{2}{|l|}{ Exposure } & \multicolumn{2}{|c|}{$\begin{array}{l}\text { Marriage } \\
\text { occurrence }\end{array}$} & \multicolumn{2}{|c|}{$\begin{array}{l}\text { Cohabitation } \\
\text { occurrence }\end{array}$} \\
\hline & $\begin{array}{c}\begin{array}{c}\text { absolute } \\
\text { value }\end{array} \\
\end{array}$ & $\%$ & $\begin{array}{c}\text { absolute } \\
\text { value }\end{array}$ & $\%$ & $\begin{array}{c}\text { absolute } \\
\text { value } \\
\end{array}$ & $\%$ \\
\hline \multicolumn{7}{|l|}{ Employment } \\
\hline not employed & 763,108 & 44.93 & 884 & 14.70 & 311 & 21.79 \\
\hline permanent employment & 625,976 & 36.85 & 3.534 & 58.75 & 726 & 50.88 \\
\hline temporary employment & 103,996 & 6.12 & 380 & 6.32 & 114 & 7.99 \\
\hline atypical job & 9,870 & 0.58 & 34 & 0.57 & 14 & 0.98 \\
\hline self-employment & 195,571 & 11.51 & 1.183 & 19.67 & 262 & 18.36 \\
\hline \multicolumn{7}{|l|}{ Educational attainment } \\
\hline upper-secondary education & 528,187 & 31.10 & 2.402 & 39.93 & 581 & 40.71 \\
\hline in education & 432,899 & 25.49 & 376 & 6.25 & 189 & 13.24 \\
\hline primary education & 664,277 & 39.11 & 2.804 & 46.62 & 528 & 37.00 \\
\hline tertiary education & 73,158 & 4.31 & 433 & 7.20 & 129 & 9.04 \\
\hline \multicolumn{7}{|l|}{ Macro-area of residence } \\
\hline North of Italy & 713,665 & 42.02 & 2.338 & 38.87 & 857 & 60.06 \\
\hline Center of Italy & 296,761 & 17.47 & 1.051 & 17.47 & 280 & 19.62 \\
\hline South of Italy & 688,095 & 40.51 & 2.626 & 43.66 & 290 & 20.32 \\
\hline \multicolumn{7}{|l|}{ Calendar time } \\
\hline before 1994 & 965,640 & 56.85 & 3.797 & 63.13 & 416 & 29.15 \\
\hline 1994-1997 & 158,791 & 9.35 & 498 & 8.28 & 139 & 9.74 \\
\hline 1997-2003 & 302,593 & 17.82 & 934 & 15.53 & 419 & 29.36 \\
\hline 2003-2006 & 134,920 & 7.94 & 412 & 6.85 & 256 & 17.94 \\
\hline after 2006 & 136,577 & 8.04 & 374 & 6.22 & 197 & 13.81 \\
\hline
\end{tabular}


Vignoli, Tocchioni \& Salvini: Insights into the role of job precariousness in union formation in Italy 